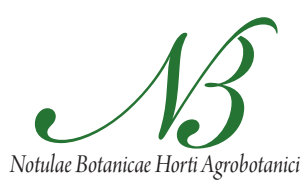

Cluj-Napoca

\title{
Micropropagation of Anubias barteri var. Nana from Shoot Tip Culture and the Analysis of Ploidy Stability
}

\author{
Kantamaht KANCHANAPOOM ${ }^{1 *}$, Panyaros CHUNUI², Kamnoon KANCHANAPOOM ${ }^{2}$ \\ ${ }^{1}$ Prince of Songkla University, Faculty of Science, Department of Molecular Biotechnology and Bioinformatics, \\ Hat Yai, Songkhla, 90112 Thailand; kantamaht@hotmail.com ("corresponding author) \\ ${ }^{2}$ Prince of Songkla University, Faculty of Science, Department of Biology, Plant Biotechnology \\ Research Unit, Hat Yai, Songkhla, 90112 Thailand; kamnoon_k@yahoo.co.th
}

\begin{abstract}
Plant regeneration of Anubias barteri var. Nana was achieved through organogenesis in shoot tip cultures. Multiple shoots were induced from cultured shoot tips on a modified MS (Murashige and Skoog, 1962) medium supplemented with BA and kinetin. The maximum green shoot numbers were best obtained on MS medium containing $3 \mathrm{mg} / \mathrm{L}$ BA with 5 shoots. Rooting in all regenerated shoots was promoted on MS medium devoid of plant growth regulators or kinetin singly. Acclimatization and survival when transferred to field conditions were shown to be $100 \%$ in the regenerated plants. Cytological and flow cytometric analyses of the mother plants and in vitro grown plants derived from 5 years old cultures showed no differences in ploidy level, they were all diploid $(2 \mathrm{n}=2 \mathrm{x}=48)$ with a 2C peak indicating that ploidy alteration did not occur.
\end{abstract}

Keywords: aquatic plant, Araceae, flow cytometry, nuclear DNA content

\section{Introduction}

The genus Anubias of the family Araceae is divided into many varieties such as Anubias barteri var. Barteri, A. barteri var. Angustifolia, $A$. barteri var. Caladiifolia, $A$. barteri var. glabra, and $A$. barteri var. Nana (Kasselmann, 2003). The most cultivated and commercially important species is $A$. barteri var. Nana which is commonly grown in aquaria. Anubias can be propagated vegetatively using stolon division; however, stolon division is an inefficient propagation method for commercial purposes since the planting material has a very low multiplication rate. Micropropagation is currently applied to aquatic plants as a tool for large scale multiplication of elite plants (Carter et al., 2011; Myung et al., 2010). However, information concerning details of media and growth regulator amendments is still a fundamental requirement of the intense commercial production of $A$. barteri.

The chromosome number of $A$. barteri var. Nana is very difficult to assess since they are small and numerous. Flow cytometry is being used to analyze DNA content in a number of plant species; which require only a small amount of tissue and is therefore non-destructive. In this context, this study investigated an efficient protocol for $A$. barteri var. Nana multiplication. The study also investigated the effects of plant growth regulators on number of chromosomes using flow cytometry as rapid methods for detecting ploidy levels in regenerated plants.

\section{Materials and methods}

\section{Plant materials}

Young plantlets of $A$. barteri var. Nana were obtained from the Aquatic Plant Center Co., Ltd., Thailand. They were surface sterilized using $0.5 \%(\mathrm{w} / \mathrm{v})$ mercuric chloride solution containing 2 drops of Tween-20 emulsifier per $100 \mathrm{ml}$ solution for $3 \mathrm{~min}$. The treated plantlets were washed three times with sterile distilled water to remove traces of disinfectant. The explants were then surface sterilized again using a dilution of $10 \%(\mathrm{v} / \mathrm{v})$ commercial Clorox $^{\mathrm{Tm}}$ which yields $5.25 \% \mathrm{NaOCl}$ and 2 drops of Tween 20 per $100 \mathrm{~mL}$ solution for $15 \mathrm{~min}$, followed by $5 \%$ (v/v) Clorox $^{\text {Tx }}$ for $5 \mathrm{~min}$. After the surface decontamination was completed the explants were rinsed 3 times with sterile distilled water. Following disinfection 3-5 mm shoot tip explants were excised prior to culture on MS (Murashige and Skoog, 1962) basal medium containing 3\% sucrose to grow the explants.

\section{Medium preparation and culture conditions}

After 6 weeks of culture, well developed shoots were obtained. The small shoots with a pair of leaves were transferred to MS medium supplemented either with $0,1,3$, or $5 \mathrm{mg} / \mathrm{L} \mathrm{BA}$ or $0,1,3$, or $5 \mathrm{mg} / \mathrm{L}$ kinetin. All culture media consisted of MS salts and vitamins supplemented with $3 \%$ sucrose and $0.82 \%$ Mermaid $^{\mathrm{TM}}$ agar. The $\mathrm{pH}$ of media was adjusted to 5.8 with $1 \mathrm{~N} \mathrm{NaOH}$ or $1 \mathrm{~N} \mathrm{HCl}$ prior to autoclaving at $1.05 \mathrm{~kg} / \mathrm{cm}^{2}, 121^{\circ} \mathrm{C}$ for $20 \mathrm{~min}$. Cultures were 
maintained at $25 \pm 1^{\circ} \mathrm{C}$ in a culture room with a 16 -h light photoperiod. All explants were subcultured at 8-week intervals. Cultures were maintained at $25 \pm 1^{\circ} \mathrm{C}$ in a culture room with a $16 / 8 \mathrm{~h}$ light/dark photoperiod under an illumination of $20 \mu \mathrm{molm}^{-2} \mathrm{~s}^{-1}$ photosynthetic photon flux intensity provided by cool white fluorescent light. Plant materials were stored in glass-capped culture jars $(115 \mathrm{ml}$ capacity) each containing $20 \mathrm{ml}$ of medium.

\section{Chromosome counting}

To determine an accurate ploidy level, chromosome counting was carried out on young root tips of in vitro grown plants. Actively growing root tips ca. $5-10 \mathrm{~mm}$ in length were excised and pretreated with saturation solution of Para dichlorobenzene for $24 \mathrm{~h}$ at $4^{\circ} \mathrm{C}$. They were fixed in fresh solution of Carnoy's fluid (3 parts $95 \%$ ethanol and 1 part glacial acetic acid) for 24 hours and stored in $70 \%$ ethanol at $4^{\circ} \mathrm{C}$. This treatment was followed by hydrolysis in $1 \mathrm{~N} \mathrm{HCl}$ at $60^{\circ} \mathrm{C}$ for 5-6 min. Finally, they were rinsed with tap water and stained in carbol fuchsin. The stained regions of root tips (0.5-1 mm long) were cut and squashed on a slide and cover with a cover slip. The chromosomes counts were carried out at 1000x magnification under light microscope (Olympus model $\mathrm{CH}$ 30, Japan) and the chromosomes of 7-8 cells were counted in three replications.

\section{Flow cytometry analysis}

Approximately $20-30 \mathrm{mg}$ of fully expanded young leaves of the mother plants and in vitro grown plants were harvested and transferred to glass Petri dish containing nuclei extraction buffer. The glass Petri dish was placed on top of ice in a bucket and nuclei were mechanically isolated by chopping leaf materials using a sharp razor blade. After chopping, the suspension was filtered through a 42 $\mu \mathrm{m}$ nylon mesh and CyStain UV Ploidy (DAPI staining solution) was added. The fluorescence of a minimum of 5000 DAPI-stained nuclei per sample was estimated using a PA-II flow cytometer (Partec, Germany). The reference standard plant (Zea mays cv. CE-777; 2C $=5.43 \mathrm{pg}$ ) was kindly provided by Dr. Jaroslav Dolezel, Laboratory of Molecular Cytogenetics and Cytometry, Institute of Experimental Botany, Czech Republic. The reference standard peak was adjusted to show at channel 100 of relative fluorescence intensity for instrument calibration. The 2C DNA content was calculated according to the formula

$$
2 \mathrm{CDNA}=\frac{\text { Sample G1 peak mean } \times \text { Standard 2CDNA content }}{\text { Standard Gl peak mean }}
$$

\section{Statistical analysis}

All experiments were carried out at least 3 times with 5-10 replicates per treatment. The fluorescence histograms were resolved into G0/G1 (2C), S and G2/M (4C) cellcycle compartments with a peak-reflect algorithm using two Gaussian curves (WinMDI version 2.8). Data were analyzed by ANOVA and the differences among the means were compared using Scheffe's test at $p \leq 0.05$.

\section{Results and discussion}

The results of in vitro organogenesis in $A$. barteri var Nana are shown in Tab. 1. Both BA and kinetin supplements resulted in different morphogenetic responses in

Tab. 1 Effect of different concentrations of BA and kinetin combinations on shoots leaves and root regeneration of Anubias barteri

\begin{tabular}{|c|c|c|c|c|c|c|}
\hline $\begin{array}{c}\mathrm{BA} \\
(\mathrm{mg} / \mathrm{L})\end{array}$ & $\begin{array}{l}\text { Kinetin } \\
(\mathrm{mg} / \mathrm{L})\end{array}$ & $\begin{array}{l}\text { Number of shoots per } \\
\text { explant (Mean } \pm S D)\end{array}$ & $\begin{array}{l}\text { Number of leaves } \\
(\text { Mean } \pm \text { SD })\end{array}$ & $\begin{array}{c}\text { Number of leaves } \\
\text { per shoot }\end{array}$ & $\begin{array}{l}\text { Number of roots per } \\
\text { shoots (Mean } \pm S D)\end{array}$ & $\begin{array}{c}\text { Root } \\
\text { formation } \\
(\%)\end{array}$ \\
\hline \multirow{4}{*}{0} & 0 & $1.4 \pm 0.89^{c}$ & $3.8^{ \pm} 2.16^{c}$ & $3.0 \pm 1.87^{\mathrm{abcd}}$ & $2.0 \pm 2.00^{\mathrm{abc}}$ & 60 \\
\hline & 1 & $1.2 \pm 0.45^{\mathrm{c}}$ & $4.4 \pm 1.34^{c}$ & $4.0 \pm 1.41^{\mathrm{ab}}$ & $2.4 \pm 1.95^{\mathrm{ab}}$ & 80 \\
\hline & 3 & $1.2 \pm 0.45^{c}$ & $4.2 \pm 2.38^{c}$ & $3.7 \pm 2.44^{\mathrm{abcd}}$ & $3.8 \pm 4.27^{\mathrm{a}}$ & 60 \\
\hline & 5 & $1.4 \pm 0.89^{c}$ & $3.8 \pm 3.19^{c}$ & $2.1 \pm 1.52^{\mathrm{cd}}$ & $2.2 \pm 3.03^{\mathrm{abc}}$ & 40 \\
\hline \multirow{4}{*}{1} & 0 & $1.6 \pm 0.89^{c}$ & $5.4 \pm 2.79^{c}$ & $3.47 \pm 0.51^{\mathrm{abcd}}$ & $0.0 \pm 0.00^{c}$ & 0 \\
\hline & 1 & $1.2 \pm 0.45^{\mathrm{c}}$ & $4.4 \pm 1.14^{\mathrm{c}}$ & $4.4 \pm 1.14^{\mathrm{a}}$ & $0.0 \pm 0.00^{c}$ & 0 \\
\hline & 3 & $1.4 \pm 0.55^{c}$ & $5.8 \pm 1.78^{\mathrm{bc}}$ & $4.4 \pm 1.08^{a}$ & $0.0_{ \pm} 0.00^{c}$ & 0 \\
\hline & 5 & $1.0 \pm 1.58^{\mathrm{bc}}$ & $7.8 \pm 4.43^{\mathrm{bc}}$ & $2.9 \pm 0.96^{\mathrm{abcd}}$ & $0.0 \pm 0.00^{\mathrm{bc}}$ & 0 \\
\hline \multirow{4}{*}{3} & 0 & $5.0 \pm 2.12^{\mathrm{a}}$ & $13.4 \pm 5.52^{\mathrm{a}}$ & $2.9 \pm 0.42^{\mathrm{abcd}}$ & $0.0 \pm 0.00^{c}$ & 0 \\
\hline & 1 & $2.4 \pm 1.14^{\mathrm{bc}}$ & $5.0_{ \pm} 2.12^{c}$ & $2.0 \pm 0.71^{\mathrm{d}}$ & $0.0 \pm 0.00^{c}$ & 0 \\
\hline & 3 & $1.8 \pm 1.06^{\mathrm{bc}}$ & $5.2 \pm 2.80^{c}$ & $3.87 \pm 1.04^{\mathrm{abc}}$ & $0.0 \pm 0.00^{c}$ & 0 \\
\hline & 5 & $1.8 \pm 1.10^{\mathrm{bc}}$ & $7.2 \pm 4.65^{\mathrm{bc}}$ & $4.1 \pm 1.02^{\mathrm{ab}}$ & $0.0 \pm 0.00^{c}$ & 0 \\
\hline \multirow{4}{*}{5} & 0 & $3.4 \pm 1.34^{\mathrm{b}}$ & $10.4 \pm 3.04^{\mathrm{ab}}$ & $3.3 \pm 0.97^{\mathrm{abcd}}$ & $0.0 \pm 0.00^{c}$ & 0 \\
\hline & 1 & $3.0 \pm 2.00^{\mathrm{bc}}$ & $8.20 \pm 3.76^{b c}$ & $3.1 \pm 0.82^{\mathrm{abcd}}$ & $0.0 \pm 0.00^{c}$ & 0 \\
\hline & 3 & $2.0 \pm 1.41^{b c}$ & $6.6 \pm 4.27^{\mathrm{bc}}$ & $3.5 \pm 0.50^{\mathrm{abcd}}$ & $0.0 \pm 0.00^{c}$ & 0 \\
\hline & 5 & $2.4 \pm 0.89^{\mathrm{bc}}$ & $6.0 \pm 3.46^{\mathrm{bc}}$ & $2.4 \pm 0.55^{\text {bcd }}$ & $0.0 \pm 0.00^{c}$ & 0 \\
\hline
\end{tabular}
var. nana

The different letters within column show significant difference (Mean \pm SE.) analyzed by Scheffe's test at $p<0.05$. 
150

terms of shoot, leaf and root formation, number of leaves per shoot, and percentage of root formation. At low concentration of $\mathrm{BA}(0,1 \mathrm{mg} / \mathrm{L})$ regenerated single shoot while an increase in BA concentration from 3 to $5 \mathrm{mg} / \mathrm{L}$ resulted in increased number of shoots per explant. The data in Tab. 1 revealed that the maximum number of $5 \pm 2.12$ shoots per explant was obtained on MS medium supplemented with $3 \mathrm{mg} / \mathrm{L} \mathrm{BA}$

The results show that BA used singly was important for induction of axillary bud outgrowth in A. barteri var. Nana. By successive subculture on MS medium containing $3 \mathrm{mg} / \mathrm{L} \mathrm{BA}$, masses of proliferating shoot cultures were established (Fig. 1a).

A significant difference in the number of leaves was detected among the treatments containing BA and kinetin. Regenerated shoots had higher number of leaves on MS medium supplemented with kinetin alone. Leaves were formed at a high frequency of $13.4(p \leq 0.05$, Tab. 1$)$ on MS medium supplemented with $3 \mathrm{mg} / \mathrm{L}$ BA. No leaf was observed on the control explants. The feature of leaves developed on MS medium containing $1-5 \mathrm{mg} / \mathrm{L} \mathrm{BA}$ and $1-5 \mathrm{mg} / \mathrm{L}$ kinetin showed broad and dark green leaves (Fig. 1a). BA seemed to inhibit root formation since the root formation was recorded only on culture media con-

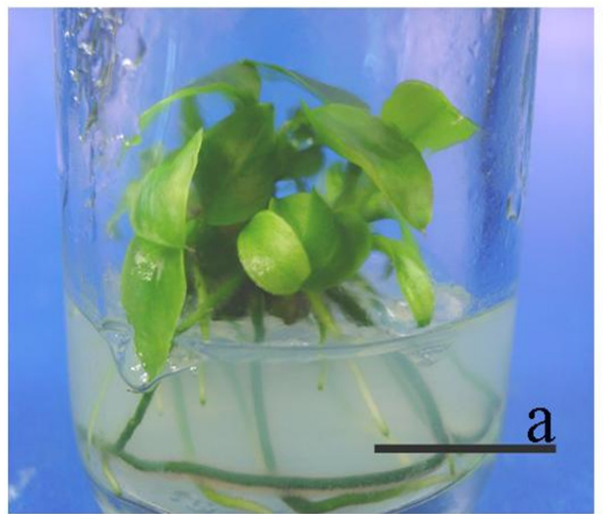

taining MS medium (control) or kinetin singly (Tab. 1). The roots arising from the basal end of shoots were large and vigorous (Fig. 1a). The explants were subcultured for 5 years successfully and did not show any morphological abnormality when compared with the non tissue cultured plants.

The cytological study of root tips at metaphase of long term cultures revealed complete accurate counts of 48 chromosomes (Fig. 1b). An occurrence of chromosome changes has been often observed during application of tissue culture, especially in plants, callus or cells that were maintained for long-term cultures in vitro (Hao and Deng, 2002). The distribution of the nuclei extracted from both the mother plants and in vitro grown plants displayed a prominent peak at $2 \mathrm{C}$ indicating that they consisted of cells with G0/G1 phase of cell cycle thus no ploidy variation occurred (Fig. 2). The mean 2C DNA content of the mother plants and in vitro grown plants are 5.43 and 5.45 pg $2 \mathrm{C}^{-1}$, respectively. This finding confirmed that the alteration of DNA content was not observed among in vitro grown plants compared to the mother plants probably due to the reason that plants regenerated from well-developed meristematic tissues that had minimum tendency of genetic variation (Rout et al., 1998).

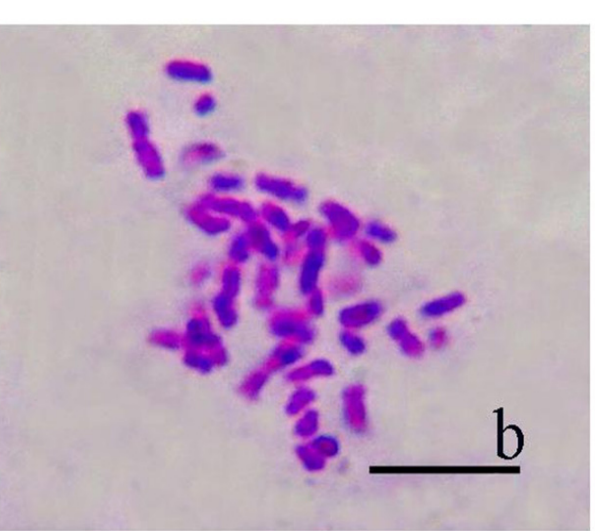

Fig. 1. In vitro propagation of Anubias barteri var. Nana (a) Multiple shoots formation from a single shoot explant after eight weeks cultured on MS medium supplemented with $3 \mathrm{mg} / \mathrm{L} \mathrm{BA}$ $($ Scale bar $=10 \mathrm{~mm})(\mathrm{b})$ Mitotic metaphase of root tips showing diploid $2 \mathrm{n}=2 \mathrm{x}=48$ chromosomes $($ Scale bar $=50 \mu \mathrm{m})$
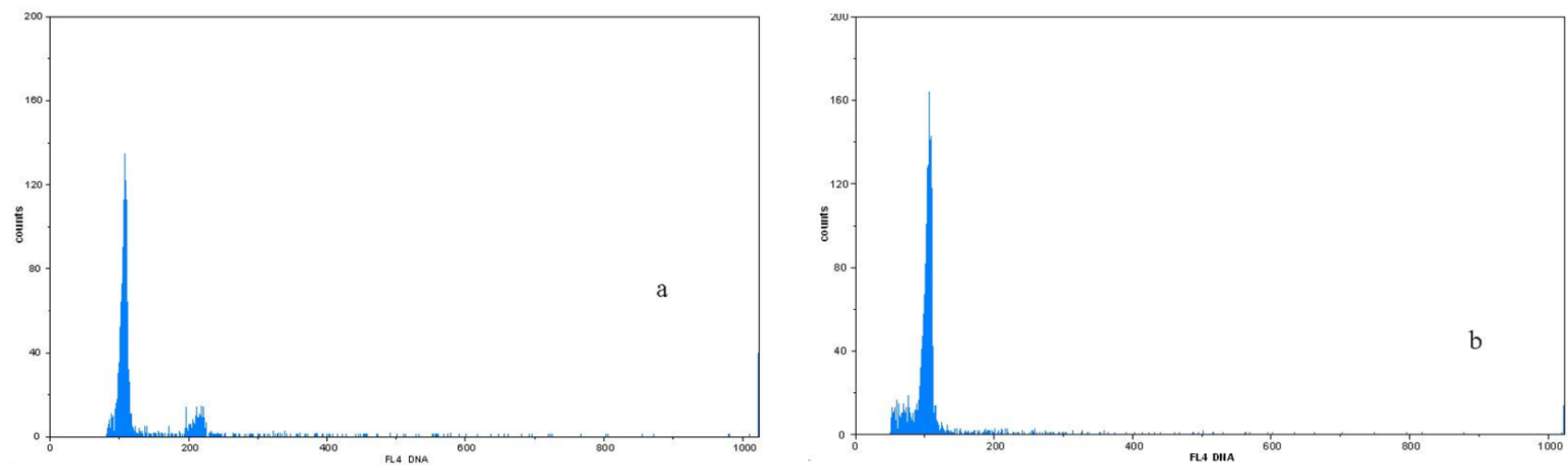

Fig. 2. Flow cytometric histograms of the relative nuclear DNA content (in channel numbers) of $A$. barteri var. Nana with (a) diploid profiles of standard plant (b)diploid profile of 5 years old in vitro grown plant 
In conclusion, we demonstrated that the establishment of rapid in vitro plant propagation of $A$. barteri var. Nana can be achieved. The nuclear DNA content value for $A$. barteri var. Nana was provided. Ploidy variations were not observed during subculture in 5 years as detected by cytological study and flow cytometry. A combination of cytological study and flow cytometry achieved better results in terms of both accuracy and rapidity.

\section{Acknowledgements}

This research was financially supported by the Faculty of Science, Prince of Songkla University, Thailand. The authors are grateful to Dr. Brian Hodgson for assistance with English and useful comments on this manuscript.

\section{References}

Carter J, Gunawardena AHLAN (2011). Regeneration of the aquatic monocot Aponogeton madagascariensis (lace plant) through callus induction. Aquat Bot 94:143-149.

Dolezel J, Greilhuber J, Lucretti S, Meister A, Lysak MA, Nardi L, Obermayer R (1998). Plant genome size estimation by flow cytometry: inter-laboratory comparison. Ann Bot 82:17-26.

Hao YJ, Deng XX (2002). Occurrence of chromosomal variations and plant regeneration from long-term cultured citrus callus. In Vitro Cell Dev Biol Plant 38:472-480.

HuangL, Chang Y, Chang Y (1994). Rapid invitro multiplication of the aquatic angiosperm, Anubias barteri var. undulata. Aquat Bot 47:77-83.

Kane ME, Gilman EF, Jenks MA, Sheehan TJ (1990). Micropropagation of the aquatic plant Cryptocoryne lucens. HortSci 25:687-689.
Kane ME, Greg L, Davis1 GL, McConnell DB, Gargiulo JA (1999). In vitro propagation of Cryptocoryne wendtii Aquat Bot 63:197-202.

Kasselmann C (2002). Aquarium Plants. Malabar, FL: Krieger Publishing Co., 104 p.

Murashige T, Skoog F (1962). A revised medium for rapid growth and bioassays with tobacco tissue culture. Physiol Planta 15:473-479.

Myung JO, Hye RN, Hong-Keun C, Jang RL, Suk WK (2010). High frequency plant regeneration system for Nymphoides coreana via somatic embryogenesis from zygotic embryoderived embryogenic cell suspension cultures. Plant Biotechnol Rep 4:125-128.

Predieri S (2001). Mutation induction and tissue culture in improving fruits. Plant Cell Tiss Org Cult 64:185-210.

Rout GR, Das P, Goel S, Raina SN (1998). Determination of genetic stability of micropropagated plants of ginger using random amplified polymorphic DNA (RAPD) markers. Bot Bull Acad Sin 39:23-37.

Trewavas AJ, Cleland RE (1983). Is plant development regulated by changes in concentration of growth substances or by changes in the sensitivity? Trends in Biochem Sci 8:354357.

Zhou C, An S, Jiang J, Yin D, Wang Z, Fang C, Sun Z, Chen Qian C (2006). An in vitro propagation protocol of two submerged macrophytes for lake revegetation in east China. Aquat Bot 85:44-52. 